\title{
Skin Squamous Cell Carcinoma or Other Skin Carcinomas pNO TNM Finding v7
}

National Cancer Institute

\section{Source}

National Cancer Institute. Skin Squamous Cell Carcinoma or Other Skin Carcinomas pNO

TNM Finding v7. NCI Thesaurus. Code C88484.

Skin squamous cell carcinoma or other skin carcinomas without regional lymph node metastases. (from AJCC 7th Ed.) 